\title{
Hibiscus sabdariffa L., roselle calyx, from ethnobotany to pharmacology
}

This article was published in the following Dove Press journal:

Journal of Experimental Pharmacology

28 February 2012

Number of times this article has been viewed

\author{
Octavio Carvajal-Zarrabal' \\ Dulce María \\ Barradas-Dermitz ${ }^{2}$ \\ Zaida Orta-Flores ${ }^{2}$ \\ Patricia Margaret \\ Hayward-Jones' \\ Cirilo Nolasco-Hipólito ${ }^{3}$ \\ M Guadalupe Aguilar- \\ Uscanga ${ }^{2}$ \\ Anilú Miranda-Medina ${ }^{2}$ \\ Kopli Bin Bujang ${ }^{3}$ \\ 'University of Veracruz, Veracruz, \\ Mexico; ${ }^{2}$ Veracruz Institute \\ of Technology, Veracruz, Mexico; \\ ${ }^{3}$ University of Malaysia Sarawak, \\ Kuching, Malaysia
}

Correspondence: Octavio

Carvajal-Zarrabal

SS Juan Pablo II s/n, Fracc.

Costa Verde, Boca del Río,

Veracruz, México, CP 94294

Tel +52 229921874 I

Fax +52 2297752036

Email ocarvajal@uv.mx
Abstract: Using MEDLINE and SCOPUS databases, a review of the literature from the pioneering study of 1991 until 2010 was performed on the effects on biological models of Hibiscus sabdariffa L. roselle calyx, its extracts mainly in polar solvents, or pure components found in extracts, as well as their possible relationship to these effects. Three relevant effects on lipid metabolism, antihypertensive activity, and apoptosis were observed. Our chronological review of the studies mentioned in the literature provides another opportunity to see how humans compile scientific knowledge of a chemical structure-physiological activity relationship starting from an ethnobotanical-ethnopharmagognosy contribution. The chemical components that are the main active principles in the physiological activities of Hibiscus sabdariffa L. calyx are anthocyanins and polyphenols (protocatechuic acid and quercetin). Advances have also been made in the elucidation of action mechanisms. Additionally, it has become clear that the lack of standardization in terms of chemical components of the material arising from Hibiscus sabdariffa L. used in testing on biological models imposes limits on the possibility of carrying out comparative analyses between studies. Fortunately, more recent studies are overcoming this obstacle by reporting component concentrations of assumed active principles; however, complete analysis of the extract, if this is to be considered as a therapeutic agent, is not commonly reported in the aforesaid studies. If one of the eventual scenarios for Hibiscus sabdariffa L. calyx is as a therapeutic agent in communities with economic limitations, then studies of a pharmacological nature should guarantee the effectiveness, safety, and tolerability of this material, which is widely accepted to be associated with chemical complexity, thus making this knowledge necessary.

Keywords: anthocyanins, phenolic, polyphenolic compounds, lipid metabolism, antihypertensive, apoptosis, safe effective herbal therapeutic product

\section{Introduction}

Throughout the development of science and especially from the second half of the 20th century onwards, Lerner's affirmation has become evident: "Everything that goes on in biology or medicine has a chemical basis." ${ }^{2}$ This relationship between chemistry and biology has generated the disciplinary field of chemical and biological sciences, which studies the basis or understanding of biological behavior through chemical language.

In the case of the components of the Hibiscus sabdariffa L., $(H s)$ or roselle, flower, this relationship between its chemistry and physiological effects in animal or human models is a matter of study, most relevantly in countries or regions where it is consumed as a refreshing drink, or where it is included in traditional medicine..$^{1,3-21}$ 
Ethnobotany and ethnopharmacognosy, the basis of useful knowledge on plants in their relationship with traditional or popular therapeutic uses, constitute a guide for chemicalpharmacological and physiological studies that allow the establishment of a scientific foundation for supposed therapeutic properties.

Farnsworth $^{22}$ notes that 119 active principles with well known chemical nature "are still isolated from higher plants, and are used in allopathic medicine". Farnsworth goes on to note that $74 \%$ of these active principles were discovered when chemists tried to identify the reason for their use in traditional medicine.

Consequently, the investigation of the constituent properties of $H s$ calyx and its relationship with possible active principles, from the pioneering work ${ }^{1}$ until 2010, represents a logical systematic process for the generation of the required chemical-biological knowledge that allows the elucidation of the possible structure-function relationship.

Among the properties reported to date for $H s$ calyx (by itself, its extracts - mainly in polar solvents - as well as isolated constituents from these extracts), its effect on lipid metabolism, its antihypertensive action, and its relationship with apoptosis or programmed cellular death are outstanding. The present study summarizes and analyzes the advances that have been achieved in the search for the relationship between these properties and the chemical nature of $H s$ constituents. Our findings complement and update the information reported previously in the literature. ${ }^{23,24}$

\section{Chemical composition}

The organic chemical constituents reported before 2003 for $H s$ calyces were included in a compendium of medical plants of the world. ${ }^{7}$ Since 2003, the literature has expanded the available information on these components. Figure 1 shows the structures for two simple phenolic compounds (protocatechuic acid [PCA] and eugenol), flavonoid-type polyphenol compounds (3-glucoside anthocyanins, anthocyanidins; flavonol quercetin), organic acids and their derivatives, vitamin $\mathrm{C}$ (ascorbic acid), $\mathrm{B}_{1}$ (thiamin), and $\mathrm{B}_{2}$ (riboflavin), and a carotenoid ( $\beta$-carotene).

Table 1 reports the results of research carried out by three different groups ${ }^{25-27}$ on proximal chemical analyses of the calyx with samples from Nigeria.

Even though the analytical methods all researchers refer to are from the Association of Official Analytical Communities (AOAC), the direct comparison of results cannot strictly be carried out. Among other reasons, the values included in both works from 2006 do not correspond to those accepted as "dry basis" (adjustment assuming 100\% total solids), even though one of them does contain values of means \pm standard deviation (SD). In the proximate or Weende chemical analysis, the desirability of avoiding the effect of dilution due to variable amounts of water in samples is recognized. The composition should be expressed on a dry basis in order to be able to make comparisons under equal conditions. Reports of proximate chemical analyses of diverse materials exist where percentage of humidity is included. Its exclusion from the adjustment allows for a total greater than 100\%. Thus, the concept of "dry basis" is satisfied on the one hand and sample humidity is included on the other hand. Table 2 includes the results of research carried out on the mineral composition of $H S$ calyx samples. ${ }^{25-28}$

Studies applied to diverse samples of plants have confirmed that the type of soil the plants grow in influences its ash or mineral content, and this can cause wide variations within the same species. ${ }^{29}$ Significant differences between mineral contents reported for these samples (eg, $\mathrm{Ca}, \mathrm{Fe}$, or $\mathrm{Mg}$ ) could mainly be because the origin of the soil is different. Nevertheless, standardization in terms of these factors could favor the therapeutic objective or not, as the case may be. The presence and concentration of pesticides as well as heavy metals and aflatoxins in calyx or extract should also be investigated.

\section{Physiological effects: chemical composition Lipid metabolism}

Pioneering research work on the component structureactivity relationship of $H_{s}$ calyx ${ }^{1}$ found that the dried calyx produced a favorable physiological reaction when administered in the diet of albino rats with induced dyslipidemia, considered as a disorder of lipid-transporting molecules in the blood (lipoprotein metabolism) whose expression can occur as a result of a rise in cholesterol or triacylglyceride concentration, or both. The latter situation, known as mixed hyperlipidemia, is characterized by high levels of lowdensity lipoprotein-cholesterol (LDL-C), non-high-density lipoprotein-cholesterol (non-HDL-C) and triacylglycerides, as well as by reduced HDL-C levels. ${ }^{30}$

Epidemiological studies carried out in other countries as well as in Mexico have shown the relationship between dyslipidemia and cardiovascular risk. ${ }^{31-38}$ In the case of Mexico,${ }^{31}$ there were 282 people (12.8\%) with mixed hyperlipidemia from a total of 2206 cases studied in 1993. The final 
<smiles>O=C(O)c1ccc(O)c(O)c1</smiles>

Protocatechuic acid<smiles></smiles><smiles>CCCCc1ccc(O)c(OC)c1</smiles><smiles>O=C(O)CC(O)(CC(=O)O)C(=O)OC1CCCC1</smiles>

Citric acid<smiles>CCC(=O)CC(O)C(O)C(=O)O</smiles>

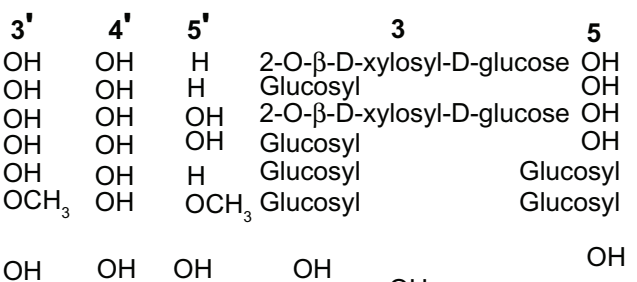

$\mathrm{OH} \quad \mathrm{OH} \quad \mathrm{OH} \quad \mathrm{OH}$ $\mathrm{OH}$<smiles>COc1c(-c2ccc(O)c(O)c2)oc2cc(O)cc(O)c2c1=O</smiles>

Quercetin-3-O-rutinoside
$\mathrm{HOOCCOOH}$

Oxalic acid
(-) - Malic acid<smiles>O=C(O)C[C@@H](O)C(=O)O</smiles>

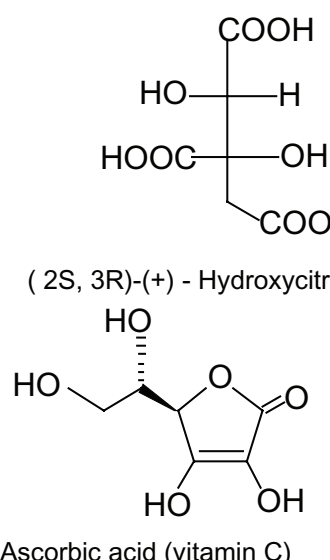

Ascorbic acid (vitamin C)

acid or hibiscus acid<smiles>O=C(O)[C@@H](O)[C@@H](O)C(=O)O</smiles>

(+)-Tartaric acid

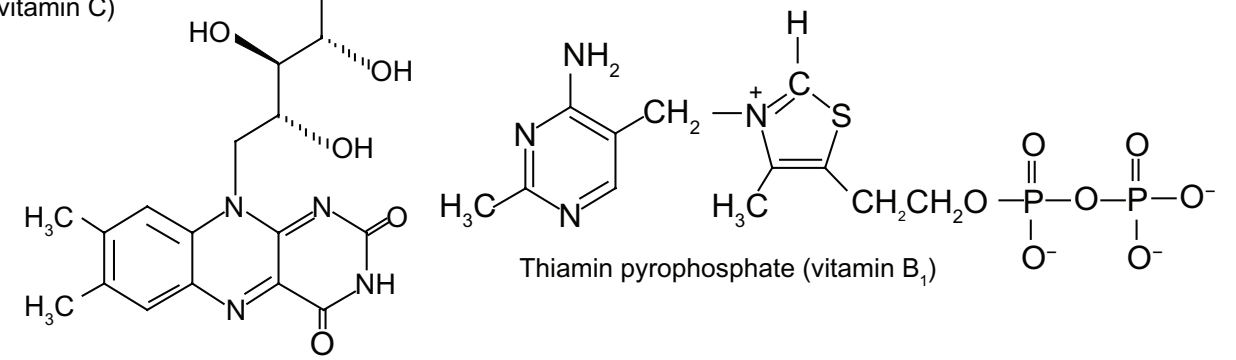

Riboflavin (vitamin $\mathrm{B}_{2}$ )

Figure I Organic compounds reported in Hibiscus sabdariffa (roselle) calyces.

report from the panel of experts in the National Cholesterol Education Program (NCEP) ${ }^{39}$ established LDL-C as the "primary objective of therapy to lower cholesterol" as it is the lipoprotein with the highest atherogenicity.

The NCEP panel also considered that although LDL-C continues as the main focus of attention in clinical practice, there exists growing evidence that very-low-density lipoprotein-cholesterol (VLDL-C) and HDL-C play an important role in atherogenesis. Therefore, attention needs to be paid to these lipoprotein-cholesterols in the integrated management of patients with cardiovascular disease.

In order to prevent these lipidemic abnormalities and to treat and control them, the NCEP places a high priority on lifestyle change (diet and physical exercise) as well as the 
Table I Proximal chemical analysis of Hibiscus sabdariffa (roselle) calyx

\begin{tabular}{|c|c|c|c|}
\hline & g/l00 g, dry basis ${ }^{25}$ & g/l00 g, dry basis ${ }^{26}$ (sic) & g/l00 g, dry basis ${ }^{27}$ (sic) \\
\hline & Mean \pm (not stated in article) & Mean \pm SD & Mean of two determinations \\
\hline Ash & $6.52 \pm 0.03$ & $6.6 \pm 0.1$ & 12.24 \\
\hline Fat & $5.13 \pm 0.01$ & $\mathrm{I} .4 \pm 0.4$ & 2.01 \\
\hline Crude fiber & $2.70 \pm 0.01$ & $9.1 \pm 1.0$ & 4.69 \\
\hline Humidity & & $9.4 \pm 1.2$ & 7.60 \\
\hline Protein & $6.40 \pm 0.01$ & $14.7 \pm 2.5$ & 4.71 \\
\hline Carbohydrates & $79.25 \pm 0.02$ & $58.6 \pm 1.8$ & 68.75 \\
\hline
\end{tabular}

Abbreviation: SD, standard deviation.

use of drugs. Some of the drugs approved for the reduction of lipids are:

A. Statins (atorvastatin, fluvastatin, lovastatin, pravastatin, rosuvastatin, and simvastatin), which act as competitive inhibitors for hydroxymethylglutaryl-coenzyme A (HMG-CoA) reductase, an enzyme that catalyzes the limiting step of cholesterol biosynthesis.

B. Fibrates (derived from fibric acid, ie, 5(2,5-dimethylphenoxy)-2,2-pentanoic acid, eg, gemfibrozil, bezafibrate, and fenofibrate), which induce lipoprotein lipolysis by diminishing levels of apolipoprotein C-III (a lipoprotein lipase inhibitor).

C. Bile acid sequesters (eg, cholestyramine, cholestipol). The activity of these compounds is through an ionic transfer between the carboxylate group of disassociated bile acids and the exchangeable ion of anionic resins (cholestyramine, cholestipol), thus interrupting enterohepatic recirculation. Three enzyme systems are affected: phosphatidic acid phosphatase, cholesterol 7 alpha-hydroxylase, and HMG-CoA reductase.

D. Cholesterol absorption inhibitors (eg, ezetimibe). Competition exists between the metabolite ezetimibeglucuronide and the exogenous cholesterol transport system, thus preventing its incorporation into the liver.
E. Nicotinic acid or niacin, which acts by inhibiting hormone-sensitive triacylglyceride lipase (HSL), with the subsequent reduction of free fatty acids in plasma. HSL catalyzes the limiting step in lipolysis: hydrolysis of tri-, di-, and monoglycerols, as well as cholesterol esters.

The inclusion of the names and mechanisms of action of the approved lipid reduction drugs listed above permits a direct comparison between the outcome of the experimental studies using $H_{s}$ calyx or isolated compounds (Table 3 ), and the possible mechanisms of action that have been identified by the corresponding researchers.

Summaries of and comments on the series of studies on animal and human models which indicated antihyperlipidemic activity of $\mathrm{Hs}$ calyces extracts or compounds are listed below in chronological order (Table 3). The year, model used, reference, and observations from the research are presented.

In summary, some researchers have provided suggestions on the possible mechanisms involved to explain the antihyperlipidemic activity shown in animal and human models.

Some extract constituents, such as PCA, anthocyanins, and polyphenols, by trapping reactive oxygen species (ROS) in both plasma and interstitial fluid of the arterial wall are likely to act by inhibiting LDL oxidation and therefore atherosclerosis onset.

Table 2 Selected mineral composition of Hibiscus sabdariffa (roselle) calyces (dry basis)

\begin{tabular}{|c|c|c|c|}
\hline & $\begin{array}{l}\mathrm{mg} / 100 \mathrm{~g} \text { simple } \\
\text { Mean } \pm \text { (not stated in article) }\end{array}$ & $\begin{array}{l}\text { mg/l00 g simple }{ }^{28} \\
\text { Mean } \pm \text { SD }\end{array}$ & $\begin{array}{l}\mathrm{mg} / 100 \mathrm{~g} \mathrm{simple}{ }^{27} \\
\text { Mean of two determinations }\end{array}$ \\
\hline Calcium, $\mathrm{Ca}$ & $3.00 \pm 0.01$ & $970 \pm 90$ & 12.65 \\
\hline Copper, Cu & $0.70 \pm 0.06$ & ND & ND \\
\hline Phosphorus, P & $22.00 \pm 0.21$ & ND & 36.30 \\
\hline Iron, Fe & $833.00 \pm 0.64$ & $17.7 \pm 0.1$ & 3.22 \\
\hline Magnesium, Mg & $1.00 \pm 0.06$ & $215 \pm 4$ & 38.65 \\
\hline Manganese, Mn & ND & ND & 2.39 \\
\hline Nickel, Ni & ND & ND & 1.78 \\
\hline Potassium, $\mathrm{K}$ & ND & ND & 49.35 \\
\hline Sodium, $\mathrm{Na}$ & $15.33 \pm 0.02$ & ND & 96.66 \\
\hline Zinc, Zn & $1.17 \pm 0.04$ & $2.8 \pm 0.2$ & 12.22 \\
\hline
\end{tabular}

Abbreviations: ND, not determined; SD, standard deviation. 
Table 3 Studies on animal and human models which indicate antihyperlipidemic activity of $H s$ calyx extracts or its isolated compounds (I991-2010)

\begin{tabular}{lll}
\hline Year & Model & Research \\
\hline 199I & Rat' & The action of $H s$ extract on the lipidic profile of albino rats (total lipids, cholesterol, phospholipids, and triacylglycerides)
\end{tabular}
was investigated. The animals underwent an adaptation period of 2 weeks with a normal diet. They were divided into two groups, group I continued being fed with the basal diet (negative control), and group 2 underwent a hypercholesterolemic regime for 12 weeks. After this time, group 2 was divided into three subgroups, and fed with an atherogenic regime: group I (positive control), group 2 (plus 5\% extract), and group 3 (plus 10\% extract). At the end of the treatment, a marked decrease in the different lipidic fractions was observed in spite of the atherogenic diet. Phospholipid levels were the only exception, increasing with extract administration. A significant decrease in glutamate-oxaloacetate transaminase (GOT) and glutamate-pyruvate transaminase (GPT) activity was also induced. Protocatechuic acid (PCA) and esculetin (ECT) antioxidant capacity for low-density lipoprotein (LDL) oxidation, induced by $\mathrm{Cu}^{+2}$ and sodium nitroprusside (SNP) was assessed. The results indicate that PCA as well as ECT exhibited inhibitory LDL activity. This same experimental model also presents an inhibitory effect on the degradation of cholesterol present in LDL and on Apo B fragmentation. When comparing PCA and ECT effects on LDL oxidation with other antioxidants, the results were similar to those of curcumin or vitamin $C$ at the same concentration, but greater than those for vitamin $\mathrm{E}$. The mechanisms responsible for this inhibiting effect on LDL oxidation are still uncertain. Some authors indicate that PCA and ECT could reduce the formation of free radicals mediated by $\mathrm{Cu}^{+2}$ with a protective effect on $\mathrm{LDL}$ by impeding lipid peroxide formation.

2003 Rabbit ${ }^{8} \quad$ Hypolipidemic and antisclerotic effects of $\mathrm{Hs}$ extract were studied for 10 weeks in five groups of rabbits (New Zealand) with experimentally induced atherosclerosis. The first group received a basal diet; the second, the same diet plus $1 \% \mathrm{Hs}$ extract in order to observe secondary effects of the extract; the third group was fed an atherogenic diet; the fourth and fifth groups had respectively $0.5 \%$ and $1 \% \mathrm{Hs}$ extract added to the basal diet. Triacylglyceride, cholesterol, and LDL serum levels in rabbits of the fourth and fifth groups decreased significantly with respect to group 3. Triacylglycerides decreased by $46 \%$ and $59 \%$ respectively in the fourth and fifth groups. There were no changes in the high-density lipoprotein-cholesterol (HDL-C) levels in either group.The LDL-C/HDL-C ratio only decreased significantly in group four $(0.5 \% \mathrm{Hs})$. Histopathological analyses of groups 4 and 5 $(0.5 \%, 1 \% \mathrm{Hs}$, respectively) compared with those of group 3 , reveal that the formation of foam cells (LDL-oxidized) is reduced, and its migration towards smooth muscle cells is inhibited. In addition, blood vessel calcification decreases. The results suggest that $\mathrm{Hs}$ extract can sequester the reactive oxygen species in plasma as well as in the interstitial fluid of the arterial wall, inhibiting LDL oxidation and therefore the onset of atherosclerosis.

2003 Rabbit $^{6}$ The results published in this patent application correspond to the contents of the article "Hibiscus sabdariffa extract inhibits the development of atherosclerosis in cholesterol-EDF rabbits", where the author establishes a method to counter LDL oxidation, to diminish triacylglycerides or cholesterol and to inhibit atherosclerosis using $\mathrm{Hs}_{\mathrm{s}}$ extract.

2004 Human LDL $^{9}$ Hs extract antioxidant capacity for LDL oxidation and its effect on the lipid profile in two systems with induced hyperlipidemia (with high-fructose diet [HFD] and high-cholesterol diet [HCD], respectively) was assessed. The results show that $H$ s extract significantly inhibits both LDL lipid electrophoretic mobility and peroxidation induced by $\mathrm{Cu}^{+2}$ ions. Hs extract also exhibited a remarkable ability to reduce both cholesterol degradation and apolipoprotein B (Apo B) fragmentation. Hs extracts displayed a great capacity to decrease triacylglyceride serum levels in animals fed with HFD, as well as cholesterol levels in animals fed with HCD. In both hyperlipidemic models, the $\mathrm{Hs}$ extract reduced LDL levels and the LDL-C/HDL-C ratio. The mechanism responsible for these effects requires elucidation. Chen and colleagues propose that some extract antioxidant constituents, such as anthocyanins and polyphenols, possibly inhibit LDL oxidation. The mechanisms underlying the antihyperlipidemic activity in animals fed with HFD and HCD diets should be determined.

2005 Rat $^{13}$ The effect of ethanolic $\mathrm{Hs}$ calyx extract on the lipidic profile in rats after a I-week atherogenic diet was assessed. The rats were divided into four groups and maintained for 4 weeks: the control group (SDc) was fed an atherogenic diet; the diet of the three experimental groups $\left(\mathrm{SD}_{5}, \mathrm{SD}_{10}\right.$, and $\left.\mathrm{SD}_{15}\right)$ was supplemented with $5 \%, 10 \%$ and $15 \% \mathrm{Hs}$ extract, respectively. The results show that $\mathrm{Hs}$ extract at all three concentrations significantly decreases triacylglyceride, total cholesterol, LDL, and lipid levels compared with control, without significantly modifying phospholipid and HDL levels. The decrease in triacylglycerides, cholesterol, and LDL levels can be attributed to the fact that hibiscus (+) hydroxycitric acid $((+) \mathrm{HCA})$, undergoes isomerization to $(-) \mathrm{HCA}$, favored by microbial biota enzymes. This compound has an inhibiting action on citrate lyase, thus preventing acetyl-CoA generation and, in turn, triacylglyceride and cholesterol biosynthesis. The different effectiveness of the three experimental groups in diminishing cholesterol could be due to certain extract constituents present at higher concentrations which affect intestinal permeability, causing a greater amount of cholesterol to be transported to the circulation. The significant decrease in LDL in the three groups could be due to the effect of extract components on the biosynthesis of this lipoprotein. The precursor of LDL is very-low-density lipoprotein (VLDL) composed mainly of triacylglycerides, and its function is to transport them from the liver to peripheral tissues. The inhibition in triacylglyceride synthesis in the three experimental groups decreases VLDL, and therefore $\mathrm{LDL}$, concentrations. The $\mathrm{SD}_{5}$ group showed the most significant results. 
Table 3 (Continued)

\begin{tabular}{|c|c|c|}
\hline Year & Model & Research \\
\hline 2006 & $\begin{array}{l}\text { Human LDL, } \\
\text { RAW } 264.7 \text { cell } \\
\text { lines }^{16}\end{array}$ & $\begin{array}{l}\text { The effect of several } \mathrm{Hs} \text { anthocyanin (HAs) concentrations on } \mathrm{LDL} \text { oxidation induced by copper sulfate } \\
\left(\mathrm{CuSO}_{4}\right) \text {, was assessed and determined by means of electrophoretic mobility. When incubating } \\
\mathrm{LDL} \text { with } \mathrm{CuSO}_{4} \text { in the presence of I, I.5, and } 2 \mathrm{mg} / \mathrm{mL} \mathrm{HAs} \text {, its electrophoretic mobility decreased, } \\
\text { demonstrating that } \mathrm{HAs} \text { have an inhibiting effect on } \mathrm{LDL} \text { oxidation. Apo B fragmentation was } \\
\text { inhibited by } 45 \%, 49 \% \text {, and } 7 \mathrm{I} \% \text { in the presence of } 0.25,0.5 \text {, and I } \mathrm{mg} / \mathrm{mL} \mathrm{HAs} \text {, respectively. } \\
\mathrm{HAs} \text { capacity for } \mathrm{LDL} \text { oxidation inhibition was also measured, thiobarbituric acid (TBARS; mmol } \\
\text { malondialdehyde/mg protein) being used as an indicator of lipid peroxidation. HAs capacity for } \\
\text { sequestering I,I-diphenyl-2-picrilhydrazil (DPPH), a free radical used to quantify antioxidant } \\
\text { activity, was also assessed. In the TBARS tests, the HAs effective dose was I-I.5 mg/mL, } \\
\text { whereas for DPPH, } 0.5 \text { and I } \mathrm{mg} / \mathrm{mL} \mathrm{HAs} \text { exhibited }>100 \% \text { sequestration effectiveness. In addition, } \\
\text { oxidized LDL induced apoptosis in macrophages and its possible inhibition by HAs were } \\
\text { determined through the viability, morphology and expression of cellular line RAW } 264.7 \text { caspase } 3 \text {. } \\
\text { The studies carried out revealed that HAs inhibit oxidized LDL-induced apoptosis making it possible } \\
\text { for them to be used as a chemopreventive agent. Further investigation into HAs specificity and } \\
\text { mechanisms is required. }\end{array}$ \\
\hline 2006 & $\begin{array}{l}\text { Rats, } \\
\text { Human LDL }{ }^{15}\end{array}$ & $\begin{array}{l}\text { The effects of aqueous } \mathrm{Hs} \text { extract both on the lipidic profile (cholesterol, triacylglycerides, HDL, and LDL) and } \\
\mathrm{LDL} \text { antioxidation, were studied in hypercholesterolemic rats. The rats were fed for I week with a normal diet. } \\
\text { They were then randomly divided into two groups: noncholesterol-fed group (control group) and cholesterol-fed } \\
\text { group ( } 2 \mathrm{~g} / \mathrm{kg} \text { in corn oil). The control group was subdivided into two groups: group I, diet plus distilled water } \\
\text { (control I) and group 2, diet plus corn oil (control II). Rats in the cholesterol-fed group were induced to be } \\
\text { hypercholesteromic by daily administration of cholesterol }(2 \mathrm{~g} / \mathrm{kg} \text { ) in corn oil. When serum cholesterol level } \\
\text { reached } 140 \mathrm{mg} / \mathrm{dL} \text { or more, they were further subdivided into five groups ( } 3 \text { to } 7 \text { ): group } 3 \text { (plus water); group } 4 \\
\text { (plus } 10 \mathrm{mg} / \mathrm{kg} \text { atorvastatin); group } 5 \text { (plus } 250 \mathrm{mg} / \mathrm{kg} \mathrm{Hs} \mathrm{extract);} \mathrm{group} 6 \text { (plus } 500 \mathrm{mg} / \mathrm{kg} \mathrm{Hs} \mathrm{extract);} \mathrm{group} 7 \\
\text { (plus } 1000 \mathrm{mg} / \mathrm{kg} \mathrm{Hs} \text { extract). A hypolipidemic effect at doses of } 500 \text { and I } 000 \mathrm{mg} / \mathrm{kg} \mathrm{Hs} \mathrm{extract} \mathrm{(groups} 6 \text { and } 7 \text { ) } \\
\text { was observed and cholesterol, triacylglycerides, and LDL serum levels were significantly reduced. In vivo and } \\
\text { ex vivo extract antioxidant effects on LDL were revealed through the significant decrease in substances reactive } \\
\text { to TBARS, and the nonsignificantly reduced formation of conjugated dienes during LDL oxidation induced by } \\
\text { cupric sulphate. The results suggest that } \mathrm{Hs} \text { water extract exhibits both hypolipidemic and antioxidant effects. } \\
\text { Nevertheless, its action mechanisms require elucidation. }\end{array}$ \\
\hline 2006 & $\begin{array}{l}\text { Rat liver } \\
\text { and kidney } \\
\text { tissues }^{4 l}\end{array}$ & $\begin{array}{l}\text { The protective effect of an } \mathrm{Hs} \text { alcoholic extract on oxidative stress was determined in hyperammonemia in rats } \\
\text { induced by ammonium chloride }\left(\mathrm{NH}_{4} \mathrm{Cl}\right) \text {; the extension of the oxidative damage, as well as the antioxidant status } \\
\text { were also measured. Animals were divided into four groups: group I (control); group } 2 \text {, with } \mathrm{Hs} \text { extract } \\
\text { ( } 250 \mathrm{mg} / \mathrm{kg} \text { body weight); group } 3 \text {, with } \mathrm{NH}_{4} \mathrm{Cl}\left(100 \mathrm{mg} / \mathrm{kg} \text { body weight); group } 4 \text { with } \mathrm{NH}_{4} \mathrm{Cl}\right. \\
\text { (I00 } \mathrm{mg} / \mathrm{Kg} \text { body weight) plus } \mathrm{Hs} \text { extract }(250 \mathrm{mg} / \mathrm{kg} \text { body weight) for } 8 \text { weeks. Results showed that } \\
\text { ammonia and urea levels rose significantly in group 3, but they significantly decreased in group } 4 \text {. Group } 2 \\
\text { did not show any significant difference in these parameters compared to control. Group } 3 \text { liver and renal tissue } \\
\text { exhibited significantly higher levels of substances reactive to TBARS, hydroperoxide (HP), conjugated dienes (CD); } \\
\text { in the cases of superoxide dismutase (SOD), catalase (CAT), glutation peroxidase (GPx) and } \\
\text { reduced glutation (GSH) levels were significantly lower in comparison to group } 4 \text {. Group } 2 \text { did not exhibit } \\
\text { any significant difference in the levels of the parameters previously mentioned, compared to the control group. } \\
\text { It is well established that there is a relationship between hyperammonemia and oxidative stress, so the maximum } \\
\text { decrease in ammonium and urea levels observed in group } 4 \text { is probably linked to the antioxidant activity } \\
\text { of some extract constituents. }\end{array}$ \\
\hline 2007 & Human $^{20}$ & $\begin{array}{l}\text { The effect of three } \mathrm{Hs} \text { extract concentrations on human cholesterol levels (I } 75 \text { to } 327 \mathrm{mg} / \mathrm{dL} \text { ) was } \\
\text { studied for } 4 \text { weeks. Capsules of } 500 \mathrm{mg} \text { previously standardized } \mathrm{Hs} \text { extract (anthocyanins, flavonoids } \\
\text { and polyphenols, } 20.1,10 \text { and } 14 \mathrm{mg} \text {, respectively) were used.The volunteers were divided into three groups } \\
\text { that received different daily doses of } \mathrm{Hs} \text { extract: } 1500 \mathrm{mg}, 3000 \mathrm{mg} \text {, and } 4500 \mathrm{mg} \text {. Serum cholesterol levels } \\
\text { before the study (basal values) and in the second and fourth week of treatment were measured. The results } \\
\text { exhibited that, on average, there was a significant decrease in cholesterol levels in the three groups up to the } \\
4 \text { th week (2.6\%, } 4.4 \% \text {, and } 2.5 \% \text {, respectively). In those volunteers who responded to the treatment, this result } \\
\text { was observed both in the second and fourth week. The best response to the treatment was at the } 3000 \mathrm{mg} \\
\text { dose. Efficiency of cholesterol-lowering drugs, according to the World Health Organization, is stated to be } \\
9 \%, 15 \%-18 \% \text { and } 30 \% \text {, for clofibrate, etofibrate, and statins, respectively. In the present study it was found } \\
\text { that } 1500 \mathrm{mg} \text { extract daily reduces cholesterol by } 4.4 \% \text { in } 50 \% \text { of the participants, and } 3000 \text { mg by } 12 \% \text { in } 71.4 \% \\
\text { of the participants after } 4 \text { weeks (short-term research). According to the authors, later studies must extend the } \\
\text { length of clinical tests, using extract levels similar to those chosen in this study. }\end{array}$ \\
\hline
\end{tabular}


Table 3 (Continued)

\begin{tabular}{|c|c|c|}
\hline Year & Model & Research \\
\hline 2009 & Rat $^{14}$ & 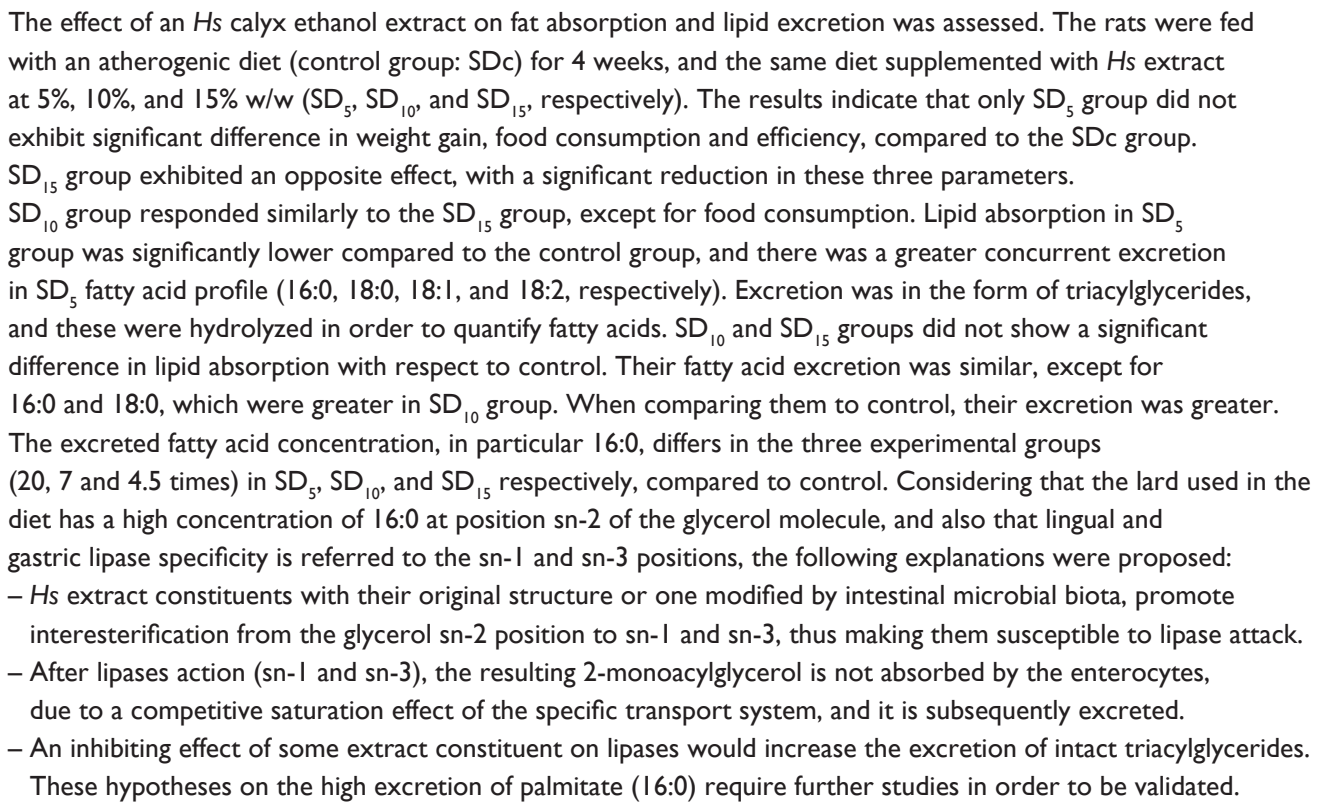 \\
\hline 2010 & $\begin{array}{l}\text { Hamster and } \\
\text { human } \\
\text { hepatocyte } \\
\text { cell line } \\
\text { HepG } 2^{42}\end{array}$ & $\begin{array}{l}\text { The effect of } H s \text { extract and } H s \text { polyphenols was investigated using hamsters. After one week of appropriate } \\
\text { acclimatization, the hamsters were divided into } 6 \text { groups.; a control group fed a standard diet, one fed only } \\
\text { an atherogenic diet, two groups with an atherogenic diet plus two different } H s \text { extract levels }(I \%, 2 \% \mathrm{w} / \mathrm{w}) \text {, } \\
\text { and two on atherogenic diet, but supplemented with } \mathrm{Hs} \text { polyphenols }(0.1 \%, 0.2 \% \mathrm{w} / \mathrm{w}) \text {. The experiment under } \\
\text { these conditions lasted } 10 \text { weeks. Both } \mathrm{Hs} \text { extract and polyphenols exhibited a hypolipidemic effect shown } \\
\text { by a decrease in plasma and liver lipid levels, polyphenols being more potent in their action (total cholesterol } \\
\text { decrease more than } 60 \%) \text {. Another contribution of this work deals with the outcome of the studies made on } \\
\text { hepatocytes HepG } 2 \text { where cytotoxicity with } \mathrm{Hs} \text { polyphenols at levels higher than I } \mathrm{mg} / \mathrm{mL} \text { was observed, } \\
\text { although with } \mathrm{Hs} \text { extract cell viability remains high (I00\%) even at } 4.5 \mathrm{mg} / \mathrm{mL} \text {. They also conducted experiments } \\
\text { that revealed the effect of } H s \text { extract and polyphenols in the dose-dependent decrease in fatty acid synthase } \\
\text { and HMG-CoA reductase, through AMPK activation and sterol regulatory element binding protein SREBP-I } \\
\text { reduction, all of which lead to a decrease in hepatocyte lipid content. }\end{array}$ \\
\hline
\end{tabular}

Hibiscus acid (+)hydroxycitric acid ((+)-HCA) undergoes racemization to $(-) \mathrm{HCA}$, favored by microbial enzymes. (-)HCA has an inhibitory action on citrate lyase, thus preventing acetyl-CoA generation and hence triacylglyceride and cholesterol biosynthesis.

Extract constituents promote interesterification from the sn-2 position of glycerol to sn-1 and sn-3, thus promoting triacylglyceride degradation by lingual and gastric lipases, with the concomitant excretion of fatty acids. Inhibition of lingual and gastric lipases by extract constituents increases intact triacylglyceride excretion.

In ex vivo experiments, Yang and colleagues ${ }^{42}$ verified the antihyperlipidemic action of aqueous $H_{s}$ extract, and specially indicated one type of component, the polyphenols. They proposed a decrease in hepatocyte lipid content resulting from dose-dependent fatty acid synthase and HMG-CoA reductase, through adenosine monophosphate-activated protein kinase activation and sterol regulatory elementbinding protein (SREBP-1) reduction.

\section{Antihypertensive effects}

Based on data from the National Health Survey ${ }^{43}$ implemented in 2000, the prevalence of hypertension in Mexico was $30.5 \%$ (34.2\% in males and $26.3 \%$ in females). While hypertension has previously been associated with populations of industrialized countries, according to the World Health Organization, this risk factor is now considered as a global health problem.

The consequences of hypertension are implicated in the development of cerebrovascular diseases, cardiac ischemia, as well as cardiac and renal failure. In turn, high blood pressure is included in the so-called metabolic syndrome, along with a high lipid profile (triacylglycerides, cholesterol, LDL). 
Among the drugs used in allopathic medicine for the treatment of hypertension are: $\mathrm{CO} 3$ diuretics (eg, thiazides and analogs), CO2 antiadrenergic agents (eg, doxazosin), angiotensin-converting enzyme (ACE) inhibitors (eg, lisinopril), calcium-channel blockers (eg, amilodipine), beta blockers (eg, propanolol) and angiotensin II receptors (eg, saralasin and related analogs).

In chronological order, Table 4 summarizes studies in animal and human models related to the antihypertensive activity of $H_{s}$ calyx, its extracts, or isolated compounds. The year, model used, references, and observations from the research are presented.

According to studies on the antihypertensive effect of $H s$ extract constituents, the researchers suggest the following probable mechanisms generally carried out in the renin-angiotensin-aldosterone blood pressure control system: aldosterone antagonist activity, similar to drugs such as spironolactone, leading to a diuretic effect; inhibition of ACE; muscarinic receptor activation of smooth muscle causing the release of nitric oxide or endothelial-relaxing factor; a vasodilator effect via endothelium-dependent and -independent mechanisms, with the dependent pathway through activation of nitric oxide/cyclic guanosine monophosphate, and the independent pathway probably by inhibiting calcium ion flow into the cytosol.

In a systematic review of work published from 1991 to January 2009 related to the antihyperlipidemic capacity of $H s$, Wahabi and colleagues ${ }^{55}$ selected four studies, ${ }^{4,11,12,48}$ all of which were carried out on humans. The analysis of the methodological procedures applied in these four studies was performed according to the Jadad scale. ${ }^{56}$ Although there was one study ${ }^{12}$ that scored higher (Jadad scale $>3$ ), the conclusion Wahabi and colleagues ${ }^{55}$ reached was that all the studies analyzed "do not provide reliable evidence to support $H_{s}$ for the treatment of primary hypertension in adults".

One of the characteristics that Wahabi and colleagues identified as lacking in these studies is related to allocation concealment, which should be included in future studies. The high score achieved by the study also led Wahabi and colleagues to recommend, amongst other things, the conduct of studies with standardized active ingredient doses and for the studies to be developed over longer periods to detect possible adverse effects.

\section{Effect on apoptosis}

Apoptosis or programmed cell death: a brief review The scientific literature reviewed up to now includes this property or characteristic for $H s$ calyx extract or for some constituents isolated from it. To realize the relative use of the concept of apoptosis and the as-yet-incomplete explanation of the mechanisms associated with it, a summarized review of apoptosis will be integrated here so that later its relation to $H s$ can be ascertained. This topic is dealt with in depth elsewhere. ${ }^{57}$

The term, apoptosis $(\mathrm{Gk}$. apo $=$ to start off from and ptosis $=$ fallen), was integrated into scientific vocabulary in the $1970 \mathrm{~s},{ }^{58}$ to describe a specific form of cellular death, a normal physiological component in development as well as in growth. Unlike necrosis, represented by lysis and death of the cell by an uncontrolled process, apoptosis is a genetically regulated route to maintain homeostasis in multicellular organisms.

An erroneous or unregulated operation of apoptosis is related to diverse health problems. Increased apoptosis is observed in neurodegenerative diseases such as Parkinson's or Alzheimer disease, in autoimmune disorders, cardiac afflictions and infectious diseases including acquired immunodeficiency syndrome. ${ }^{59}$ On the other hand, decreased apoptosis characterizes cancer. Generally, two molecular mechanisms of apoptosis are accepted, based on the origin of the stimulus or signal: intrinsic or extrinsic (Figure 2). In both mechanisms, caspases (cystein-containing aspartatespecific proteases) are present. Caspases are a family of cystein proteases (cystein at its active site) that carry out the breaking of peptide bonds in proteins at the P1 site, next to an aspartate residue.

In the intrinsic mechanism, the mitochondria receives a signal produced by cellular stress, which in turn can be caused among others factors by viral infection, damage to the DNA, deprivation of growth factors, or by oxidative stress by ROS. Members of the Bcl-2 protein family (an oncoprotein) pro-apoptotics such as Vax, Bim, and Bad, as well as antiapoptotics Bcl-2 and $\mathrm{Bcl}-\mathrm{xL}$, regulate the liberation of cytochrome $\mathrm{C}$ to the cytosol, and this sets in motion the caspase activation chain. When it is united with the Apaf-1 protein (apoptotic protease activator-1 factor) and adenosine triphosphate, this complex oligomerizes to be united with procaspase 9 to compose the well-known formation of an apoptosome. Subsequent to this formation, procaspase 9 rupture takes place which gives rise to the activation of a caspase effector, such as caspase 3 .

In the case of the extrinsic mechanism, caspase activation implies initially the union of proteins binding death inducers to cellular surface receptors (death receptors). One of the most studied extrinsic mechanisms is the interaction of the Fas receiver, CD95, or APO-1, with the Fas-L ligand. 
Table 4 Studies on animal and human models which indicate antihypertensive activity of $H s$ calyces, $H s$ calyx extracts, or its isolated compounds (1991-2010)

\begin{tabular}{cl}
\hline Year & Model \\
\hline $199 \mid$ & a) Smooth muscle: \\
& rabbit (aorta), rat \\
& (uterus and diaphragm), \\
& guinea pig (trachea), \\
& and frog \\
& (rectus abdominis); \\
& b) Anesthetized cats ${ }^{44}$ \\
1999 & Human ${ }^{4}$
\end{tabular}

\section{Research}

The possible antispasmodic effect of $H s$ calyces on various muscle preparations (rabbit aorta, rat uterus and diaphragm, guinea pig trachea, and frog rectus abdominis) was investigated. Aqueous $\mathrm{Hs}$ extracts ( $2.5 \mathrm{ml}$ per sample, equivalent to a concentration of $50 \mathrm{mg} / \mathrm{mL}$ ) exercised a relaxing effect on smooth muscle and a hypotensive effect on anesthetized cats, partially blocked by atropine administration. The authors argue for the involvement of muscarinic receptors in the hypotensive action. It can be assumed that $\mathrm{Hs}$ constituents activate smooth muscle muscarinic receptors causing the release of endothelial relaxing factor (EDRF or nitric oxide).

The efficacy of aqueous $\mathrm{Hs}_{\mathrm{s}}$ extract (infusion) on hypertensive patients was evaluated. A $12.5 \mathrm{~g}$ Hs calyx infusion in $250 \mathrm{~mL}$ water was administered to an experimental group, as opposed to regular tea in a control group, for 12 days. The results showed a decrease of $11.2 \%$ in systolic and $10.7 \%$ in diastolic pressure in the experimental group after starting treatment. This pressure difference in both the systolic and diastolic was significant compared to the control group. Three days after stopping treatment, systolic pressure rose $7.9 \%$ and diastolic pressure $5.6 \%$ in both groups. Based on these results, the authors question whether the hypotensive effect is due to the diuretic effect of $\mathrm{Hs}$ or the presence of anthocyanins. Three mechanisms are proposed for the hypotensive effect: vascular resistance decreased due to inhibition of angiotensin I and angiotensin II production by ACE inhibitors; vasodilator hormone bradykinin was inactivated by ACE and levels of prostaglandins increased with a vasodilator effect. ${ }^{45}$

$1999 \mathrm{Rat}^{3}$

$2003 \operatorname{Rat}^{10}$
The effect of $\mathrm{Hs}$ extract toxicity on mice at different doses (1000, 3000 and $5000 \mathrm{mg} / \mathrm{kg}$ body weight) was evaluated. A value of $L_{50}$ above $5000 \mathrm{mg} / \mathrm{kg}$ was obtained. Also the antihypertensive action of $\mathrm{Hs}$ extract on hypertensive (SHR) and normotensive (WKY) rats was studied. Both groups were subdivided into three groups: control (group I), $500 \mathrm{mg} / \mathrm{kg}$ extract (group 2) and $1000 \mathrm{mg} / \mathrm{kg}$ extract (group 3). The results were monitored over a period of 21 days. After 7 days, there was no difference in body weight, systolic and diastolic blood pressure in SHR group I rats. After 7 days, in SHR group 2, systolic blood pressure was significantly lower than in group I, although there was no significant reduction in body weight. With respect to group 3 , death occurred in two out of five rats at 7 days. The others showed a significant reduction in systolic and diastolic blood pressure compared with the control group and their own initial values. In WKY group 3, there was no reduction in body weight, systolic or diastolic pressure. After 21 days of continuous administration of the extract, body weight, systolic and diastolic pressure were significantly lower in SHR group 2. In SHR group 3, death of the three remaining rats occurred between 7 and 21 days. WKY rats had a significant reduction in systolic and diastolic pressure in both groups 2 and 3 . In order to elucidate the possible mechanism by which the infusion of $\mathrm{Hs}$ calyx constituents lower blood pressure, the water intake, urine excretion and serum concentrations of creatinine, uric acid, cholesterol, glucose and total protein were monitored. There was no difference in water consumption in either control group. However, urine excretion in hypertensive rats (SHR group 2) was higher than in the control group. The other parameters suffered a significant decrease in rats treated with the extract, compared with the corresponding control groups, with the exception of serum uric acid levels, which showed a significant increase. This increase may be due to a change in extracellular fluid volume, there by affecting urate excretion. In sum, although the $H_{s}$ calyx infusion can be effective as an antihypertensive therapeutic agent, knowledge of toxicity thresholds is useful for studies related to safety and tolerability. The effect of aqueous $\mathrm{Hs}$ calyx extract on rats with induced renovascular hypertension by the surgical obstruction of the left renal artery $(2 \mathrm{~K}-\mathrm{IC})$ was studied. Another group underwent a simulated operation and served as control (Sh-Op). 2K-IC rats with recorded pressures above $140 \mathrm{~mm} \mathrm{Hg}$ after 6 weeks were divided into two groups: those receiving $250 \mathrm{mg} / \mathrm{kg} /$ day $\mathrm{Hs}$ extract and those given only water $(2 \mathrm{~K}-\mathrm{IC}+\mathrm{Hs}$ and $2 \mathrm{~K}-\mathrm{IC}$, respectively). At 8 weeks there was no significant difference found in blood pressure between $2 \mathrm{~K}-\mathrm{IC}+\mathrm{Hs}$ and Sh-Op groups, but chronic treatment with $\mathrm{Hs}$ ( 14 weeks) normalized blood pressure in the $2 \mathrm{~K}-\mathrm{IC}+\mathrm{Hs}$ group. A significant reduction in heart rate was observed in the $2 \mathrm{~K}-\mathrm{IC}+\mathrm{Hs}$ group compared to the $2 \mathrm{~K}-\mathrm{IC}$ group. Cardiac hypertrophy associated with hypertension was significantly attenuated with chronic administration of $H s$ extract, the heart weight of $2 \mathrm{~K}-\mathrm{IC}+\mathrm{Hs}$ group being comparable to that of Sh-Op group. The urinary flow rate in $2 \mathrm{~K}-\mathrm{IC}+\mathrm{Hs}$ group compared to $2 \mathrm{~K}-\mathrm{IC}$ group, presented no significant difference. Based on this last point, the authors suggest that diuresis is not an important mechanism in $\mathrm{Hs}$ antihypertensive action. The reduction in heart rhythm speed may be due to $H$ s inotropic effects $(-)$ and chronotropic effects $(-)$ on isolated atria as reported previously. ${ }^{10,46}$ The authors note that hypertension pathogenesis may be due to increased vascular superoxide production thereby affecting the vasodilator action of nitric oxide, but, because they did not investigate the effect of $\mathrm{Hs}$ on oxidative stress parameters, a hypothesis cannot be proposed. However, the fact that the extract is rich in vitamin $C$ and anthocyanins is mentioned, both potent antioxidants. Their function as free radical scavengers in $2 \mathrm{~K}-\mathrm{IC}$ hypertension remains speculative. Finally, this study supports the popular belief that $\mathrm{Hs}$ contains antihypertensive constituents. 
Table 4 (Continued)

\begin{tabular}{|c|c|c|}
\hline Year & Model & Research \\
\hline 2004 & Human"I & $\begin{array}{l}\text { The antihypertensive effect and tolerability of an } \mathrm{Hs} \text { extract standardized in terms of anthocyanins } \\
\text { was investigated through clinical tests, relating it to captopril. Daily administration for } 4 \text { weeks of a } \\
\text { water infusion of dry } \mathrm{Hs} \text { calyces ( } 9.6 \mathrm{mg} \mathrm{HAs} \text { ) was compared with } 50 \mathrm{mg} \text { captopril. The results confirm } \\
\text { that there was no significant difference in antihypertensive effectiveness or in tolerability in both treatments. } \\
\text { The authors mention references to previous works where diverse mechanisms through which } \mathrm{Hs}_{\mathrm{s}} \text { extract } \\
\text { can exert its hypotensive effect were explained. The increase only in urinary } \mathrm{Na}^{+} \text {excretion (not } \mathrm{K}^{+} \text {) in } \\
\text { treated patients, similar to what happens with diuretic administration of the spironolactone type } \\
\text { (aldosterone antagonist), permits the establishment of the hypothesis that } \mathrm{Hs}_{\text {s }} \text { diuretic activity is } \\
\text { probably analogous to this drug group. }\end{array}$ \\
\hline 2007 & Rat aorta ${ }^{2 !}$ & $\begin{array}{l}\text { The effect of methanolic } \mathrm{Hs} \text { calyx extract was evaluated on vascular reactivity and antihypertensive } \\
\text { mechanisms in rat aortas, previously contracted with potassium chloride }(\mathrm{KCl}) \text { and phenylephrine. } \\
\text { Methanolic } \mathrm{Hs} \text { calyx extract induced a vasodilator effect in isolated aortas of hypertensive rats. The } \\
\text { effect against contraction previously induced by phenylephrine or } \mathrm{KCl} \text { was inhibited in the absence of } \\
\text { endothelium. In the presence of endothelium-dependent (acetylcholine) or endothelium-independent } \\
\text { (sodium nitroprusside) vasodilators, their effects were significantly improved, showing that methanolic } \\
\text { Hs extract induces a vasodilator effect in aortas of hypertensive rats via a dependent as well as an } \\
\text { independent mechanism in the endothelium. Dependent pathway activation arises from the relaxing } \\
\text { effect of nitric oxide/cGMP. The independent pathway may be due to inhibition of } \mathrm{Ca}^{+2} \text { influx. }\end{array}$ \\
\hline 2007 & Human $^{12}$ & $\begin{array}{l}\text { The therapeutic efficacy, tolerability, safety, serum electrolytes, and ACE inhibition of a standardized } \\
\mathrm{Hs} \text { extract in terms of anthocyanins, was investigated in hypertensive patients and compared with lisinopril. } \\
\text { For this purpose randomized controlled double-blind clinical trials were carried out. Doses equivalent to } \\
250 \mathrm{mg} \mathrm{HAs} \text { of dried aqueous } \mathrm{Hs} \text { extract (lyophilized) were administered daily for } 4 \text { weeks and compared } \\
\text { with } 10 \mathrm{mg} \text { lisinopril. Extract safety and tolerability were } 100 \% \text { and extract therapeutic effectiveness } \\
\text { was } 65.12 \% \text { versus } 82.14 \% \text { for lisinopril. } \mathrm{Hs} \text { hypotensive effect exhibited a decrease of II.58\%/I2.2I\% for } \\
\text { systolic/diastolic pressure compared with a } 15.79 \% / I 5.68 \% \text { effect for lisinopril. The administration of } \mathrm{Hs} \\
\text { extract inhibited plasma ACE activity and showed a tendency to reduce serum } \mathrm{Na}^{+} \text {without altering } \mathrm{K}^{+} \text {levels. } \\
\text { Based on these results, the authors state that the extract's active constituents exert their hypotensive } \\
\text { activity with at least two complementary synergistic mechanisms: diuretic (probably an aldosterone antagonist) } \\
\text { and ACE inhibition. The authors report that } \mathrm{Hs} \text { possesses the properties of the two drug groups most often } \\
\text { prescribed for hypertension treatment (ACE inhibitors and diuretics), with the advantage that diuretic } \\
\text { activity does not alter } \mathrm{K}^{+} \text {levels, as is the case of diuretics of the spironolactone type. }\end{array}$ \\
\hline 2007 & Rat $^{47}$ & $\begin{array}{l}\text { Relative efficiency of aqueous } \mathrm{Hs} \text { extract was determined for } 5 \text { weeks in two models } \\
\text { of experimental hypertension in rats induced by sodium chloride }(\mathrm{NaCl}) \text { or by the methyl ester } \\
\text { of } \mathrm{N} \text {-L-arginine (L-NAME). The animals were divided into three groups: normotensive (group I), } \\
\mathrm{NaCl} \text {-induced hypertensive (group } 2 \text { ), hypertensive induced by inhibition of nitric oxide synthase } \\
\text { (L-NAME) at a dose of } 50 \mathrm{mg} / \mathrm{kg} / \mathrm{day} \text { (Group } 3 \text { ). The femoral vein was cannulated for measuring } \\
\text { blood pressure and for the administration of } \mathrm{Hs} \text { extract }(\mathrm{I}, 5,25 \text {, and I } 25 \mathrm{mg} / \mathrm{kg} \text {, respectively). } \\
\text { The results show that the average blood pressure (systolic + diastolic/2) before treatment with } \\
\text { Hs extract was significantly higher in groups of hypertensive rats (Groups } 2 \text { and } 3 \text { ) compared } \\
\text { with the control group. In turn, Group } 3 \text { had a blood pressure and heart rate significantly } \\
\text { higher than Group } 2 \text {. After intravenous administration of Hs extract at different concentrations, } \\
\text { the fall in blood pressure was significantly higher in Groups } 2 \text { and } 3 \text { than in the control. } \\
\text { At the highest extract dose (I } 25 \text { mg/kg), blood pressure in Group } 2 \text { fell I.5 times more } \\
\text { than control, while that of Group } 3 \text { fell about } 2.5 \text { times. The results show that aqueous } \\
\text { Hs extract lowers blood pressure in hypertensive and normotensive rats, this difference } \\
\text { being higher in hypertensive rats. This confirms the antihypertensive Hs activity reported } \\
\text { in other experimental models. }\end{array}$ \\
\hline 2009 & Human $^{48}$ & $\begin{array}{l}\text { This study investigated the difference in antihypertensive effect between } \mathrm{Hs} \text { tea preparation } \\
\text { and black tea. Diabetic type } 2 \text { patients with slight hypertension but consuming neither } \\
\text { antihypertensive nor antihyperlipidemic medicines were divided into two groups. In a double blind test, } \\
\text { one group consumed } \mathrm{Hs} \text { tea preparation ( } 2 \mathrm{~g} \text { calyx in } 240 \mathrm{~mL} \text { boiling water with } 5 \mathrm{~g} \text { added sugar) } \\
\text { and the other group black tea ( } 2 \mathrm{~g} \text { loose tea in } 240 \mathrm{~mL} \text { boiling water with } 5 \mathrm{~g} \text { added sugar) for } \\
\text { I month twice daily. There was no control group. For the Hs group, both systolic blood pressure } \\
\text { and pulse pressure decreased, whereas the effects were the opposite in the black tea group. } \\
\text { Diastolic pressure was not affected in either group. The authors agreed with previous studies that } \\
\text { anthocyanins in the Hs preparation are the active principles that have the greatest effect on } \\
\text { blood pressure, although the exact mechanism is not known. }\end{array}$ \\
\hline
\end{tabular}


Table 4 (Continued)

\begin{tabular}{|c|c|c|}
\hline Year & Model & Research \\
\hline 2010 & Human $^{49}$ & $\begin{array}{l}\text { This study focused on the antihypertensive effects of } H s \text { tea preparation in a randomized double-blind } \\
\text { placebo-controlled clinical trial. Healthy adults with slight hypertension but not consuming any antihypertensive } \\
\text { medicine were divided into two groups. The first group consumed } H s \text { tea preparation ( } 1.25 \mathrm{~g} H s \text { calyces in } 240 \\
\mathrm{~mL} \text { boiling water), while the second group consumed an Hs mimicking drink prepared from artificial cranberry } \\
\text { and raspberry flavor concentrates with added red color, for six weeks. Systolic blood pressure decreased } \\
\text { significantly in the Hs group (a greater decrease observed in participants with higher initial systolic blood } \\
\text { pressure readings) but not so diastolic blood pressure. Mean arterial pressure was also not affected. } \\
\text { These authors referred to previous studies that tried to elucidate the action mechanism behind this } \\
\text { antihypertensive effect generally carried out in the renin-angiotensin-aldosterone blood pressure } \\
\text { control system. }\end{array}$ \\
\hline 2010 & $\mathrm{ACE}^{50}$ & 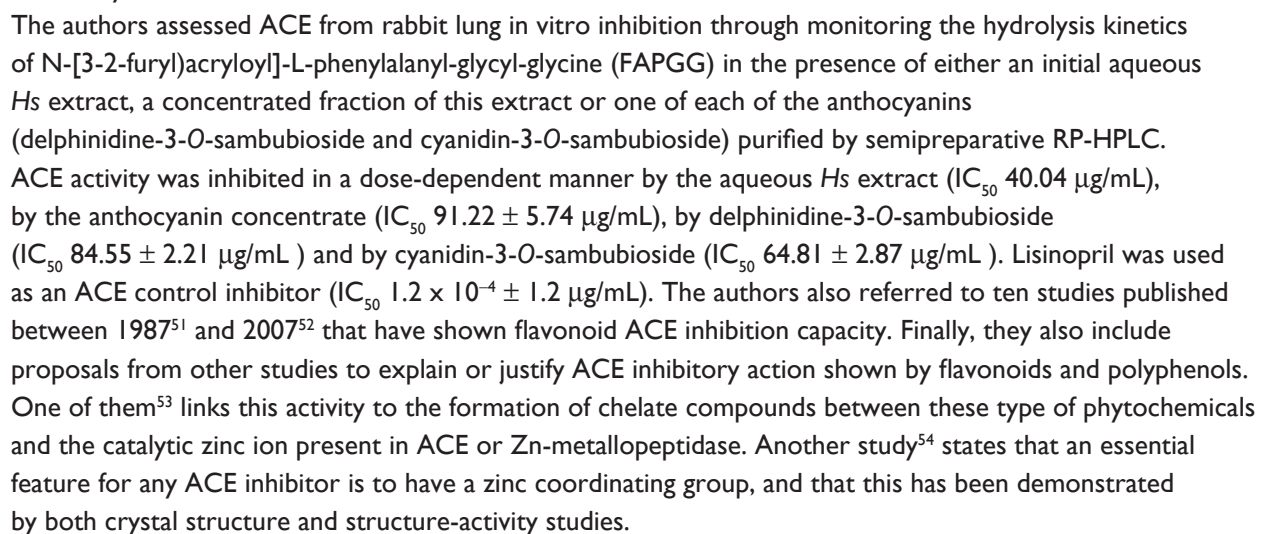 \\
\hline
\end{tabular}

This union promotes the following sequence: receptor trimerization, recruitment of specific adaptor proteins (Fasassociated protein with death domain [FADD]) and of zymogen (inactive) form molecules of caspase 8 (procaspase 8). This molecular complex (ligand-oligomer receptor+protein adaptor+procaspase), is called death-inducing signaling complex (DISC). Subsequently, procaspase- 8 is a broken, selfcatalytically producing caspase 8 (active form), which then breaks and activates caspase effectors such as caspase 3 .

The point of contact between the intrinsic and extrinsic routes occurs in the activation of another member of the Bcl-2 protein family, the Bid, a proapoptotic in this case, by caspase- 8 formed from the Fas/FADD contact. The Bid arrives at the mitochondria where it can initiate the intrinsic route.

In studies conducted ${ }^{60}$ to characterize part of the molecular events that take place in the interaction of the Fas receptor with the Fas-L ligand, events were identified related to their link to the route of mitogen-activated protein kinases (MAPK). This MAPK superfamily is composed of three main signaling routes: the extracellular signal-regulated protein kinases, the N-terminal c-Jun kinases (JNK) or stressactivated protein kinases, and the family of $\mathrm{p} 38$ kinases. ${ }^{61}$ The findings until now suggest that some of these kinases can activate the process of apoptosis initiated by the interaction of Fas with Fas-L or contribute to its rapid increase.

\section{Hs and apoptosis}

Lin and colleagues ${ }^{17,19}$ specifically refer to $H s$ extract apoptotic activity. Another three articles ${ }^{18,62,63}$ refer to the apoptotic action of 3,4-hydroxybenzoic acid or PCA, a reported component of $H s$ calyx extracts. Guan and colleagues ${ }^{63}$ also described the capacity of PCA to suppress apoptosis.

A substantial difference between the first two articles mentioned above, ${ }^{17,19}$ is the type of extract used. In the first article by Lin and colleagues, ${ }^{17}$ the experiment material was a methanolic extract ( $2 \mathrm{~g}$ dry powder, soluble in water, derived from $100 \mathrm{~g} H s$ ) characterized in terms of simple phenols (PCA, caffeic acid) and polyphenols (catechins), and in the other, ${ }^{19}$ a freeze-dried aqueous extract $(7.5 \mathrm{~g}$ from $150 \mathrm{~g}$ dry $H s$ flowers) was characterized in terms of polyphenols, flavonoids, and anthocyanins.

We summarize data from the six articles below:

In the 2005 paper by Lin and colleagues, ${ }^{17}$ treatment was carried out with methanolic $H s$ extract on seven cell cancer lines: human gastric adenocarcinoma (AGS), human promyelocytic leukemia (HL-60), hepatocellular carcinoma (Hep3B), colorectal adenocarcinoma (Caco-2), hepatoblastoma (HepG2), adenocarcinoma (MCF-7), human oral epidermoid carcinoma (KB), and one control cellular line: mouse fibroblast cells. Evaluation of implied apoptotic pathway(s) was made. Methanolic $H s$ extract induced 


\begin{tabular}{|l|}
\hline D \\
I \\
S \\
C \\
\hline
\end{tabular}

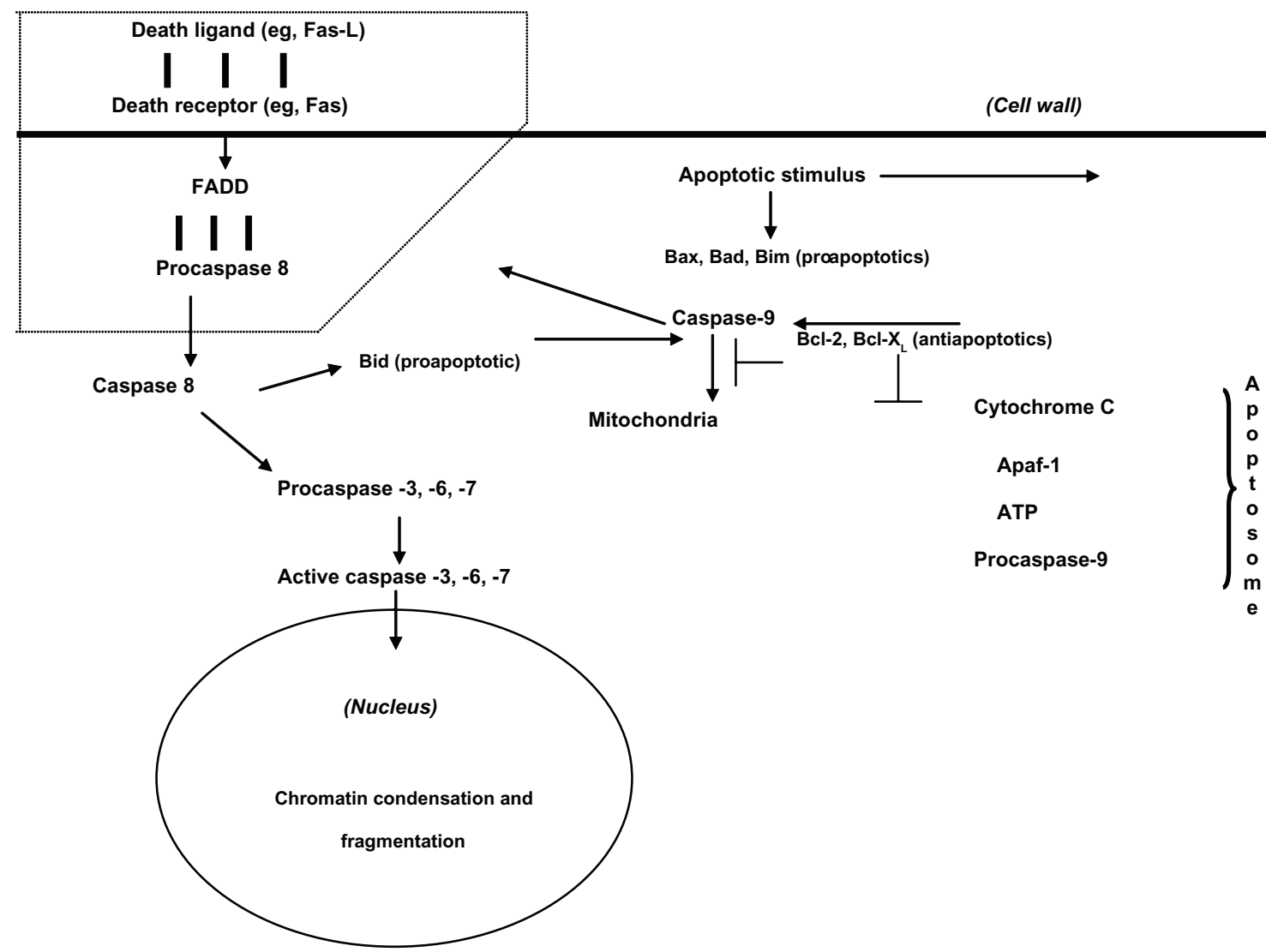

Figure 2 Apoptotic cell pathways: death receptor or extrinsic pathway (Fas/FADD/Caspase 8/3) and mitochondrial pathway or intrinsic pathway (Cytochrome C/Apaf-I/ Caspase 9).

Simplified and adapted from Nijhawan et al. ${ }^{57}$

apoptosis in all cellular lines (seven cancer lines and one control) in a concentration-dependent form. The AGS cells were the most susceptible with a drug concentration resulting in $50 \%$ in vitro inhibition $\left(\mathrm{IC}_{50}\right)$ of $0.95 \mathrm{mg} / \mathrm{mL}$ compared to control cells ( $\mathrm{IC}_{50}$ of $2.98 \mathrm{mg} / \mathrm{mL}$ ). Evidence that methanolic $H s$ extract promoted both apoptotic routes (intrinsic: phosphorylation by kinase p53; extrinsic: phosphorylation by kinase p-38) was observed.

In the 2007 paper by Lin and colleagues, ${ }^{19}$ treatment with aqueous $H s$ extract was carried out on two cell lines, one cancerous, AGS, and control, Chang hepatic cells (normal cells). Evaluation of implied apoptotic pathway(s) was made. The extract demonstrated effectiveness (cytotoxicity and apoptosis) on the AGS cellular line in a concentration-dependent form, but not on control cells. It was observed that aqueous $H s$ extract promoted both apoptotic routes. The fundamental difference between the present proposal of these authors compared with their 2005 proposal is that now the extract initially activates JNK and p38 MAP-kinases "that subsequently phosphorylate the c-Jun target protein and transduce the signal to activate the apoptotic protein cascade later that contains the signaling mediated by Fas (signaling module: FasL/Fas/caspase 8/t-Bid.)". In synthesis, it is the point of contact between the extrinsic and intrinsic routes, caspase 8/Bid, that explains the double apoptotic route proposed by Lin and colleagues for the action of aqueous $H s$ extract.

In the 2000 paper by Tseng and colleagues, ${ }^{62}$ Treatment was carried out on HL-60 and Bcl-2 overexpressed human leukemia cells (HL60/Bcl-2-350), with PCA (0.2 to $2 \mathrm{~mm}$ ) isolated from $H s$. Inhibition of HL-60 cell survival was dependant on PCA concentration and time ( $2 \mathrm{mM}$; 9 hours). There was a delay in PCA-induced apoptosis in HL60/Bcl-2-350 cells.

In the 2004 paper by Kampa and colleagues, ${ }^{63}$ treatment was carried out on human breast cancer T47D cells with different phenolic acids, PCA being one of them, with an inhibiting effect on T47D cell growth observed that was 
dependent on concentration and time. Apoptosis was via Fas-FasL.

In the 2006 paper by Guan and colleagues, ${ }^{64}$ their assay involved PC12 rat pheochromocytoma cells (adrenal gland): (a) without treatment; (b) treated with a neurotoxic agent, 1-methyl-4-phenylpyridinium ion $\left(\mathrm{MPP}^{+}\right) ;(\mathrm{c}-\mathrm{e})$ treated with $\mathrm{MPP}^{+}$and increasing doses of PCA $(0.3,0.6$, and $1.2 \mathrm{mM}$, respectively). PCA significantly prevented the mitochondrial dysfunction that $\mathrm{MPP}^{+}$ion produces. $\mathrm{MPP}^{+}$ is known to induce apoptosis and is linked to a decrease in the regulation of $\mathrm{Bcl}-2$ protein family. In this case, it was observed that PCA significantly suppressed the decrease in regulation of this protein family. "PCA reduced $\mathrm{MPP}^{+}$induced apoptosis, attenuating the change of mitochondrial membrane permeability that is linked to oxidative-stress damage."

In the 2007 paper by Lin and colleagues, ${ }^{18}$ treatment was carried out on AGS cells, American Type Culture Collection CRL-1739, with PCA. An inhibitory effect on cell growth was observed, dependant on concentration and time. The $\mathrm{IC}_{50}$ at 24 hours of exposure was $7.3 \mathrm{~mm}$.

Several elements become evident from the above information. Based on the few studies done on $\mathrm{Hs}_{s}$ extracts, one proposal is that apoptosis develops by both routes (extrinsic and intrinsic), whereas those studies in which PCA has been used (also a limited number of studies), apoptosis develops by only one route. Although possible explanations have been proposed for the apoptosis models established for $H s$ extract or PCA action, there is a lack of a specific characterization of the molecular events that occur between those $H s$ active principles responsible for the signaling-route activation that triggers or regulates this particular apoptosis process. PCA's observed double functionality is relevant for the eventual therapeutic effects that could be approved for PCA, an $H s$ extract constituent. It is clear that in cancer cells where apoptosis is diminished, PCA has shown to be apoptotic in action; elsewhere, in cells like those that serve as a model to study neuronal degeneration (cells treated with $\mathrm{MPP}^{+}$), where apoptosis is increased, PCA reduces it.

\section{Summary and perspectives}

The reviewed literature mainly involved studies on animal or human models, the physiological effects of $H s$ calyx, its extract (obtained in different, generally polar, solvents), or of the pure components present in the extract. Twelve articles referred to lipid metabolism activity, eleven to the antihypertensive effect, and six are linked to apoptosis. These scientific studies conducted to date confirm the validity of some of the popular uses compiled by ethnobotany and ethnopharmacognosy of the $H s$ calyx.

Of the three biological effects (lipid metabolism, antihypertensive effect, apoptosis) the most advanced research available on the mechanism of action of $H s$ calyx or its derivatives is that of the antihypertensive effect, which is associated with anthocyanin ACE inhibitor capacity. Nevertheless, those pharmacological studies conducted on animal and human models using plant extracts (complex chemical compound mixtures), although enriching chemical-biological knowledge, have largely lacked full standardization, a situation that has been overcome by partial standardizations. Also in the case of human clinical trials, there has not been the proper allocation concealment as mentioned above. The application of standardized samples of $H s$ extracts in terms of anthocyanins, total flavonoids, polyphenols, PCA, ash, calcium, iron, and magnesium among others, could make validated comparative analyses possible, thus allowing for the association of physiological action with specific chemical constituents, as well as forming a base for research into effectiveness, safety, and tolerability. It will also be necessary to complement this chemical characterization with the determination of residual pesticides, heavy metals, and aflatoxins. A challenge still to be met is the elucidation of events related to the therapeutic action of $H s$ extract-specific compounds at the molecular level. This could explain the structure-function relationship of these compounds with their action on lipid metabolism as well as their antihypertensive, apoptotic, or antiapoptotic effects.

Future studies on $H s$ extract with greater scientific robustness will permit the formulation of safe, effective herbal therapeutic products recognized by international health organizations such as the European Medicines Agency's Committee on Herbal Medicinal Products for their use in humans in relation to the pathologies mentioned above. The calyx or $H s$ derivatives (extracts and isolated components) need to undergo complementary scientific studies in order to transition from traditional herbal medicinal products to medicinal products with acceptable levels of safety, efficiency and tolerability. This is the challenge.

\section{Acknowledgments}

To Nature for continuing to offer us reasons to admire, challenges to overcome, and communal, nonexclusive access roads to achieve health. To those groups that have preceded us, generated, and transmitted knowledge, without which today's advances could not be understood. We wish to 
thank DGEST (Dirección General de Educación Superior Tecnológica-Technological Higher Education General Directorate) for the partial financial support for the Hibiscus sabdariffa L. roselle interinstitutional research program (project No 2197.09-P).

\section{Disclosure}

The authors report no conflict of interest in this work.

\section{References}

1. El-Saadany SS, Sitohy MZ, Labib SM, El-Massry RA. Biochemical dynamics and hypocholesterolemic action of Hibiscus sabdariffa (Karkade). Nahrung. 1991;35:567-576.

2. Wilson EK. Scripps Research Institute thrives at interface of chemistry and biology. Chem Eng News. 1996;174:39-44.

3. Onyenekwe PC, Ajani EO, Ameh DA, et al. Antihypertensive effect of roselle (Hibiscus sabdariffa) calyx infusion in spontaneously hypertensive rats and a comparison of its toxicity with that in Wistar rats. Cell Biochem Funct. 1999;17:199-206.

4. Haji-Faraji MH, Haji-Tarkhani AH. The effect of sour tea (Hibiscus sabdariffa) on essential hypertension. J Ethnopharmacol. 1999;65: 231-236.

5. Wang CJ, Wang JM, Lin WL, et al. Protective effect of Hibiscus anthocyanins against ter-butyl hydroperoxide-induced hepatic toxicity in rats. Food Chem Toxicol. 2000;38:411-416.

6. Wang CJ. Method to counter oxidation LDL, decrease triacylglyceride or cholesterol and inhibit atherosclerosis using Hibiscus sabdariffa extract. United States Patient Application No 0096021. 2003 May 22.

7. Ross IA. Medicinal plants of the World. Vol I. Totawa, NJ: Humana Press; 2003.

8. Chen CC, Hsu JD, Wang SF, et al. Hibiscus sabdariffa extract inhibits the development of atherosclerosis in cholesterol-fed rabbits. J Agric Food Chem. 2003;51:5472-5477.

9. Chen CC, Chou FP, Ho YC, et al. Inhibitory effects of Hibiscus sabdariffa L extract on low-density lipoprotein oxidation and antihyperlipidemia in fructose-fed and cholesterol-fed rats. J Sci Food Agric. 2004;84:1989-1996.

10. Odigie IP, Ettarh RR, Adigun SA. Chronic administration of aqueous extract of Hibiscus sabdariffa attenuates hypertension and reverses cardiac hypertrophy in $2 \mathrm{~K}-1$ hypertensive rats. J Ethnopharmacol. 2003;86:181-185.

11. Herrera-Arellano A, Flores-Romero S, Chávez-Soto MA, et al. Effectiveness and tolerability of a standardized extract from Hibiscus sabdariffa in patients with mild moderate hypertension: a controlled and randomized clinical trial. Phytomed. 2004;11:375-382.

12. Herrera-Arellano A, Miranda-Sánchez J, Avila-Castro P, et al. Clinical effects produced by a standardized herbal medical product of Hibiscus sabdariffa on patients with hypertension. A randomized, double-blind, lisinopril-controlled clinical trial. Planta Med. 2007;73:6-12.

13. Carvajal-Zarrabal O, Waliszewski SM, Barradas-Dermitz DM, et al. The consumption of Hibiscus sabdariffa dried calyx ethanolic extract reduced lipid profile in rats. Plant Foods Hum Nutr. 2005;60:153-159.

14. Carvajal-Zarrabal O, Hayward-Jones PM, Orta-Flores Z, et al. Effect of Hibiscus sabdariffa dried calyx ethanolic extract on fat absorptionexcretion and body weight implication in rats. J Biomed Biotechnol. 2009;2009:394592.

15. Hirunpanich V, Utaipat A, Morales NP, et al. Hypocholesterolemic and antioxidant effects of aqueous extracts from the dried calyx of Hibiscus sabdariffa L. in hypercholesterolemic rats. J Ethnopharmacol. 2006;103:252-260.

16. Chang YC, Huang KX, Huang AC, et al. Hibiscus anthocyanin-rich extract inhibited LDL oxidation and oxLDL-mediated macrophages apoptosis. Food Chem Toxicol. 2006;44:1015-1023.
17. Lin HH, Huang HP, Huang CC, et al. Hibiscus polyphenol-rich extract induces apoptosis in human gastric carcinoma cells via p53 phosphorylation and p38 MAPK/FasL cascade pathway. Mol Carcin. 2005;43:86-99.

18. Lin HH, Chen JH, Huang CC, et al. Apoptotic effect of 3,4-dihydroxybenzoic acid on human gastric carcinoma cells involving JNK/p38 MAPK signaling activation. Int. J Cancer. 2007;120: 2306-2316.

19. Lin HH, Chen JH, Kuo WH, et al. Chemopreventive properties of Hibiscus sabdariffa L. on human gastric carcinoma cells through apoptosis induction and JNK/p38 MAPK signaling activation. Chem Biol Interact. 2007;165:59-75.

20. Lin TL, Lin HH, Chen CC, et al. Hibiscus sabdariffa extract reduces serum cholesterol in men and women. Nut Res. 2007;2:140-145.

21. Ajay M, Chai HJ, Mustafa AM, et al. Mechanisms of the anti-hypertensive effect of Hibiscus sabdariffa L. calyces. J Ethnopharmacol. 2007;109:338-393.

22. Farnsworth NR. The role of ethnopharmacology in drug development. In: Chadwick DJ, Marsh J, editors. Ciba Foundation 154-Bioactive Compounds from Plants. Novartis Foundation Symposia; 1990. September 28, 2007.

23. Ali BH, Naser AWN, Blunden G. Phytochemical, pharmacological and toxicological aspects of Hibiscus sabdariffa L.: A Review. Phytother Res. 2005;19:369-375.

24. Gomes ME, da Costa HR, Moreira RR, et al. Pharmacological evidences of the extracts and secondary metabolites from plants of the genus Hibiscus. Food Chem. 2010;118:1-10.

25. Nnam NM, y Onyeke NG. Chemical compositions of two varieties of sorrel (Hibiscus sabdariffa L.), calyces and the drinks made from them. Plant Foods Hum Nutr. 2003;58:1-7.

26. Ojokoh AO. Roselle (Hibiscus sabdariffa) calyx diet and histopathological changes in liver of albino rats. Pak J Nutr. 2006;5:110-113.

27. Adanlawo IG, Ajibade VA. Nutritive value of the two varieties of roselle (Hibiscus sabdariffa) calyces soaked with wood ash. PakJ Nutr. 2006;5:555-557.

28. Falade OS, Otemuyiwa IO, Oladipo A, et al. The chemical composition and membrane stability activity of some herbs used in local therapy for anemia. J Ethnopharmacol. 2005;102:15-22.

29. Bear FE, Toth SJ, Prince AL. Variation in mineral composition of vegetables. Soil Sc Soc Am Proc. 1948;13:380-384.

30. Lipids Online Educational Resources in Atherosclerosis [homepage on the Internet]. Available from: http://www.lipidsonline.org/clinicalcases/mixed-hyperlipidemia/. Accessed September 28, 2010.

31. Aguilar-Salinas CA, Rojas R, Gómez-Pérez FJ, et al. Characteristics of mixed hyperlipidemia cases in a population-based study: Results from the Mexican National Survey of Chronic Diseases. Salud Pública de México. 2002;44:546-553.

32. Cullen P, Schulte H, Assmann G. The Münster Heart Study (PROCAM). Circulation. 1997;96:2128-2136.

33. Law MR, Wald NJ, Wu T, et al. Systematic underestimation of association between serum cholesterol concentration and ischemic heart disease in observational studies: data from the BUPA Study. BMJ. 1994;308:363-366.

34. Neaton JD, Blackburn H, Jacobs D, et al. For the multiple risk factor Intervention trial research group. Serum cholesterol level and mortality findings for men screened in the multiple risk factor intervention trial. Arch Intern Med. 1992;152:1490-1500.

35. Pekkanen J, Nissinen A, Punsar S, et al. Short- and long-term association of serum cholesterol with mortality: the 25-year follow-up of the Finnish cohorts of the seven countries study. Am J Epidemiol. 1992;135:1251-1258.

36. Assmann G, Schulte H. Role of triacylglycerides in coronary artery disease: lessons from the prospective cardiovascular Munster study. Am J Cardiol. 1992;70:10H-13H.

37. Wilson PFW, Abbott RD, Castelli WP. High-density lipoprotein cholesterol and mortality: the Framingham Study. Arteriosclerosis. 1988;8:737-741. 
38. Anderson KM, Castelli WP, Levy D. Cholesterol and mortality: 30 years of follow-up from the Framingham Study. JAMA. 1987;257: 2176-2180.

39. National Cholesterol Education Program (NCEP) Expert Panel on Detection, Evaluation and treatment of high blood cholesterol in adults. Third report of NCEP expert panel on detection, evaluation and treatment of high blood cholesterol in adults (Adult Treatment Panel III) Final Report. Circulation. 2002;106:3143-3421.

40. Lee MJ, Cho FP, Tseng TH, et al. Hibiscus protocatechuic acid or esculetin can inhibit oxidative LDL induced by copper ion or nitric oxide donor. J Agric Food Chem. 2002;50:2130-2136.

41. Mohamed Essa M, Subramanian P, Manivasagam T, et al. Protective influence of Hibiscus sabdariffa, an edible medicinal plant, on tissue lipid peroxidation and antioxidant status in hyperammonemic rats. African Journal of Traditional, Complementary and Alternative Medicine. 2006;3:10-21.

42. Yang MY, Peng $\mathrm{CH}$, Chan $\mathrm{KC}$, et al. The hypolipidemic effect of Hibiscus sabdariffa polyphenols via inhibiting lipogenesis and promoting hepatic lipid clearance. J Agr Food Chem. 2010;58:850-859.

43. Velázquez-Monroy O, Rosas-Peralta M, Lara-Esqueda A, et al. Arterial hypertension in Mexico: Results of the National Health Survey (ENSA) 2000 [Hipertensión arterial en México: Resultados de la Encuesta Nacional de Salud (ENSA) 2000]. Arch Card Méx. 2002;72:71-84. [Spanish.]

44. Ali MB, Salih WM, Mohamed AH, et al. Investigation of the antispasmodic potential of Hibiscus sabdariffa calyces. J Ethnopharmacol. 1991;31:249-257.

45. Bennet JC, Plum F, Wyngaarden JB. Cecil Textbook of Medicine, 20th ed. Philadelphia, PA: Saunders; 1996.

46. Tiamjan R. Hypotensive activity of Hibiscus sabdariffa Linn. MSc Thesis. Chang Mai, Thailand: Department of Pharmacology, Chiang Mai University; 1999.

47. Mojiminiyi FBO, Dikko M, Muhammad BY, et al. Antihypertensive effect of an aqueous extract of the calyx of Hibiscus sabdariffa. Fitoterapia. 2007;78:292-297.

48. Mozaffari-Khosravi H, Jalali-Khanabadi B-A, Afkhami-Ardekani M, et al. The effects of sour tea (Hibiscus sabdariffa) on hypertension in patients with type II diabetes. J Hum Hypertens. 2009;23:48-54.

49. McKay DL, Chen CY, Saltzman E, et al. Hibiscus sabdariffa L. tea (tisane) lowers blood pressure in prehypertensive and mildly hypertensive adults. J Nutr. 2010;140:298-303.

50. Ojeda D, Jiménez-Ferrer E, Zamilpa A, et al. Inhibition of angiotensin converting enzyme (ACE) activity by the anthocyanins delphinidin- and cyanidin-3-O-sambubiosides from Hibiscus sabdariffa. JEthnopharmacol. 2010;127:7-10.
51. Kameda K, Takaku T, Okuda H, et al. Inhibitory effects of various flavonoids isolated from leaves of persimmon on angiotensin-converting enzyme activity. J Nat Prod. 1987;50:680-683.

52. Loizzo MR, Said A, Tundis R, et al. Inhibition of angiotensin converting enzyme (ACE) by flavonoids isolated from Allanthus excelsa (Roxb) (Simaroubaceae). Phytother Res. 2007;21:32-36.

53. Chen CH, Lin JY, Lin, CN, et al. Inhibition of angiotensin-I-converting enzyme by tetrahydroxyxanthones isolated from Tripterosperum lanceolatum. J Nat Prod. 1992;55:691-695.

54. Spowage BM, Bruce CL, Hirst JD. Interpretable correlation descriptors for quantitative structure-activity relationships. J Cheminform. 2009; 1:22.

55. Wahabi HA, Alansary LA, Al-Sabban AH, et al. The effectiveness of Hibiscus sabdariffa in the treatment of hypertension: A systematic review. Phytomed. 2010;17:83-86.

56. Jadad AR, Moore A, Carroll D, et al. Assessing the quality of reports of randomized clinical trials: is blinding necessary? Control Clin Trials. 1996; $17: 1-12$.

57. Nijhawan D, Honarpour N, Wang X. Apoptosis in neural development and disease. Annu Rev Neurosci. 2000;23:73-87.

58. Kerr JF, Wyllie AH, Currie AR. Apoptosis: a basic biological phenomenon with wide-ranging implications in tissue kinetics. Br J Cancer. 1972;26:239-257.

59. Singh N. Apoptosis in health and disease and modulation of apoptosis for therapy: an overview. Indian J Clin Biochem. 2007;22(2):6-16.

60. Goillot E, Raingeaud J, Ranger A, et al. Mitogen-activated protein kinase-mediated Fas apoptotic signaling pathway. Proc Natl Acad Sci US A. 1997;94:3302-3307.

61. Cowan KJ, Storey KB. Mitogen-activated protein kinases: new signaling pathways functioning in cellular responses to environmental stress. J Exp Biol. 2003;206:1107-1115.

62. Tseng TH, Kao TW, Chu CY, et al. Induction of apoptosis by Hibiscus protocatechuic acid in human leukemia cells via reduction of retinoblastoma (RB) phosphorylation and Bcl-2 expression. Biochem Pharmacol. 2000;60:307-315.

63. Kampa M, Alexaki VI, Notas G, et al. Antiproliferative and apoptotic effects of selective phenolic acids on TD47 human breast cancer cells: potential mechanisms of action. Breast Cancer Res. 2004;6:63-74.

64. Guan S, Jiang B, Bao YM, et al. Protocatechuic acid suppresses $\mathrm{MPP}^{+}$-induced mitochondrial dysfunction and apoptotic cell death in PC12 cells. Food Chem Toxicol. 2006;44:1659-1666.
Journal of Experimental Pharmacology

\section{Publish your work in this journal}

The Journal of Experimental Pharmacology is an international, peerreviewed, open access journal publishing original research, reports, reviews and commentaries on all areas of laboratory and experimental pharmacology. The manuscript management system is completely online and includes a very quick and fair peer-review system.

\section{Dovepress}

Visit http://www.dovepress.com/testimonials.php to read real quotes from published authors. 